\title{
アモルファスシリコン薄膜トランジスタのオフ電流特性に 及ぼすプラズマ処理の効果
}

\author{
熟塚＼cjkstart諫*, 藪田 哲史**, 岡本 昌也*** \\ Plasma Treatment Effect on the Off Current Characteristics \\ of a-Si Thin Film Transistor
}

Isamu WASHIZUKA*, Satoshi YABUTA** and Masaya OKAMOTO***

\begin{abstract}
The off current of amorphous silicon (a-Si : H) thin film transistors (TFTs) depends on fabrication after back-channel etching. Plasma treatment after back-channel etching affects off current in the lower subthreshold voltage region. Off current is high in $\mathrm{O}_{2}$ plasma treatment and low in $\mathrm{N}_{2}$ plasma treatment. Without plasma treatment, off current can not be controlled. $\mathrm{N}_{2}$ plasma treatment affects the interface characteristics between a-Si : H layer and passivation layer, obstructing electron transport near the back-channel inerface.
\end{abstract}

Key Words : a-Si, TFT, Plasma Treatment

\section{1. 緒言}

高品位の表示が得られるアクティブマトリクス型液晶 ディスプレイ(AM-LCD)のスイッチング素子として, アモルファスシリコン薄膜トランジスタ(a-Si Thin Film Transistor, a-Si TFT)を用いた液晶ディスプレイ が, パーソナルコンピューター, 携带情報端末(PDA) といった多くの情報ツールやビデオカムコーダー, カー ナビゲーション用の画像ディスプレイとして使われるよ うになってきた。

a-Si TFT の構造は, ダート電極とソース・ドレイン 電極が a-Si 層を挟んで上下に対峙し, ゲート電極が下 側に配置される逆スタガ型構造(ボトムゲート構造)が一 般的で, その中でもバックチャネルエッチ型とチャネル 保護型の 2 種類の構造がある。

バックチャネルエッチ型の TFT の場合, チャネル保 護型に比べチャネル長 $(\mathrm{L})$ を短くできるため, 比較的容 易に高いオン電流を得ることができる。しかし, バック チャネルエッチング時のプロセス安定化のため, a-Si

*シャープ侏) 情報・プリント・通信事業統轄（テ639-1186 奈良県大和郡山市美濃庄町 492)

Information $\cdot$ Communication $\cdot$ Printing \& Reprographic Systems Management, Sharp Corp. (492, Minosho-cho, Yamato-Koriyama-shi, Nara 639-1186)

**シャープ㑣) TFT 液晶事業本部（T632-8567 奈良県天理 市絸本町 2613-1)

TFT Liquid Crystal Display Group, Sharp Corp. (26131, Ichinomoto-cho, Tenri-shi, Nara 632-8567)

***シャープ侏) 液晶開発本部（礼632-8567 奈良県天理市櫟 本町 2613-1)

Liquid Crystal Display Development Group, Sharp Corp. (2613-1, Ichinomoto-cho, Tenri-shi, Nara 632-8567)
層の膜厚を厚くしなければならないこと, チャネル表面 領域での久陥が多いこと ${ }^{1}$ などから, TFTオフ時の リーク電流が高い傾向が見られる。

本稿では, バックチャネルエッチング型 a-Si TFT の オフ電流特性を改善するために, バックチャネルエッチ ング後に $\mathrm{O}_{2}$ プラズマ処理および $\mathrm{N}_{2}$ プラズマ処理を行 い, それらがオフ電流特性に及ほす影響について検討を 行った。

\section{2. 実験方法}

\section{1 a-Si TFT の作製方法}

図 1 に本研究に用いたバックチャネルエッチ型の逆ス タガー型 a-Si TFT の断面図を示す。本研究では, 以下 の手順で a-Si TFTを作製した。

ガラス基板上にゲート電極の形成を行った後, プラズ マ CVD 法により，ゲート絶縁膜(窒化シリコン, $\mathrm{SiN}_{\mathrm{x}}$ ), 半導体層 $(\mathrm{a}-\mathrm{Si}: \mathrm{H})$, オーミックコンタクト膜を連続的 に成膜した。今回，a-Si：H 層の膜厚は $150 \mathrm{~nm}$ とした。 また,ソース・ドレイン電極と a-Si : H 膜との良好な

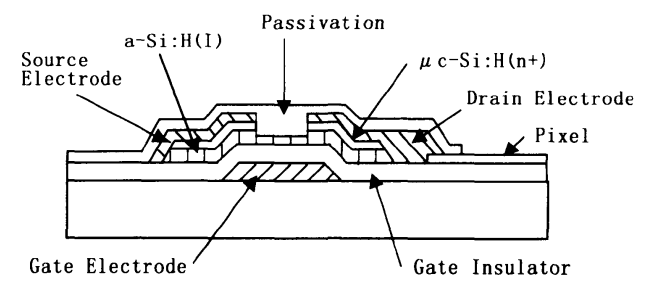

Fig. 1 Cross sectional view of the inverted staggered a-Si TFT of back channel etching type used in this study. 
オーミックコンタクトを得るために, $\mathrm{n}^{+}$型微結晶 $\mathrm{Si}$ $\left(\mu \mathrm{c}-\mathrm{Si}: \mathrm{H}\left(\mathrm{n}^{+}\right)\right)$膜をコンタクト膜とした ${ }^{2)}$ 。次に $\mathrm{n}^{+}$型 微結晶 $\mathrm{Si} / \mathrm{a}-\mathrm{Si}: \mathrm{H}$ 膜をパターン化した後, ソース・ド レイン電極を形成し，ソース・ドレイン電極間のチャネ ル領域を，通常エッチングの際にマスクとして用いるレ ジストパターンを使用せず，ソース・ドレイン電極自体 をマスクとして，ドライエッチング法でエッチングした。 この時, チャネル領域での $\mathrm{a}-\mathrm{Si}: \mathrm{H}$ 膜の残膜量が $90 \mathrm{~nm}$ となるようにエッチングを行った。エッチング終了後, エッチングガスを排気し， $\mathrm{O}_{2}$ ガス， $\mathrm{N}_{2}$ ガスを用いて バックチャネル表面のプラズマ処理を行った。プラズマ 処理は, 圧力 $200 \mathrm{~Pa}, \mathrm{RF}$ パワー密度 $0.12 \mathrm{~W} / \mathrm{cm}^{2}$, 処 理時間 45 秒の条件で行った。最後にプラズマ CVD 法 により保護膜 $\left(\mathrm{SiN}_{\mathrm{x}}\right)$ を形成した。なお，今回評価を 行ったTFTのチャネル長(L)は $4 \mu \mathrm{m}$, チャネル幅 (W) は $23 \mu \mathrm{m}$ とした。

\section{2 TFT 特性の評価方法}

TFT 特性の評価は，半導体パラメーターアナライ ザー $(\mathrm{HP} 4145 \mathrm{~B})$ を用い, ゲート電圧 $V_{\mathrm{g}}$, ソース電圧 $V_{\mathrm{ds}}$ を変化させた場合のドレイン電流 $I_{\mathrm{ds}}$ (暗電流), 光 照射下でのオフ電流，測定温度を上げていった時のオフ 電流，バイアス・温度ストレス下でのしきい值電圧およ びオフ電流について測定した。

\section{3. 実験結果および考察}

\section{1 ドレイン電流のゲート電圧依存性}

バックチャネルエッチング後に, $\mathrm{O}_{2}$ プラズマ処理, $\mathrm{N}_{2}$ プラズマ処理を行ったものとプラズマ処理を行わな

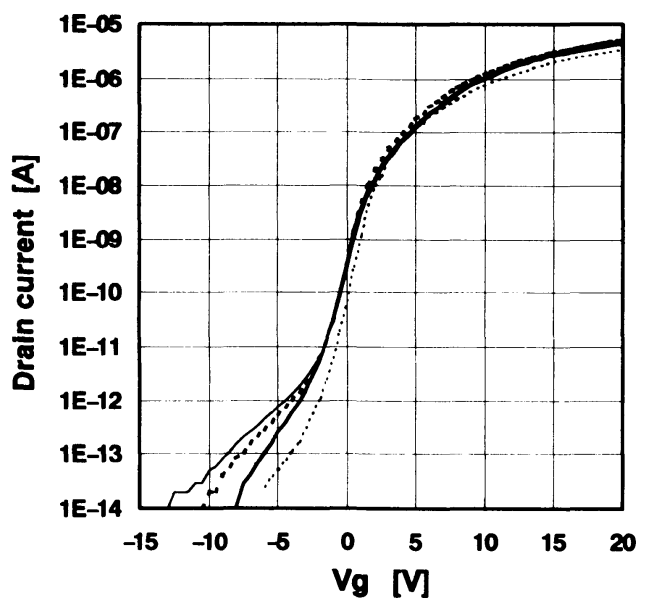

Fig. 2 TFT characteristics of the TFTs with $\mathrm{O}_{2}$ and $\mathrm{N}_{2}$ plasma treatment and without plasma treatment.
- One non treatment sample
......- Another non treatment sample
-...- $\mathrm{O}_{2}$ plasma treatment
$\mathrm{N}_{2}$ plasma treatment

いものについて, ソース電圧 $V_{\mathrm{ds}}$ を+ $10 \mathrm{~V} に$ 固定し, ゲート電压 $V_{\mathrm{g}}$ をー $15 \mathrm{~V}$ から+20 V まで変化させた場 合のドレイン電流 $I_{\mathrm{ds}}$ (暗電流)の変化を測定した。その 結果を図 2 に示す。

$\mathrm{O}_{2}$ プラズマ処理と $\mathrm{N}_{2}$ プラズマ処理を比較すると, オン電流には両処理の差はほとんど見られないが, オフ 電流は $\mathrm{N}_{2}$ プラズマ処理の方が $\mathrm{O}_{2}$ プラズマ処理より低 くなった。また，プラズマ処理を行わない場合は，オン 電流についてはプラズマ処理を行った場合とほとんど差 は見られないが，オフ電流については変動が大きく， $\mathrm{O}_{2}$ プラズマ処理を行ったものより高くなる場合と, $\mathrm{N}_{2}$ プラズマ処理を行ったものより低くなる場合があった。 これは, プラズマ処理を行わない場合, バックチャネル エッチング後のチャネル表面が不安定な状態になってい るためと考えられる。一方，プラズマ処理を行ったもの については， $\mathrm{O}_{2}$ プラズマ処理， $\mathrm{N}_{2}$ プラズマ処理のいず れについても再現性のあるオフ電流特性が得られた。
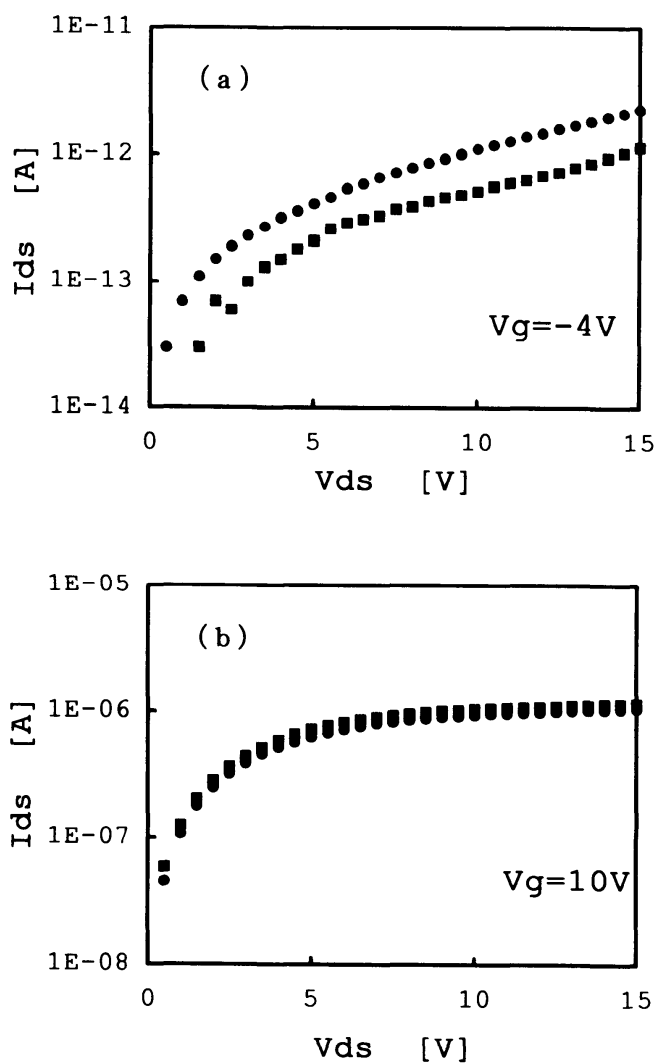

Fig. 3 Off current and on current characteristics of the TFTs with $\mathrm{O}_{2}$ and $\mathrm{N}_{2}$ plasma treatment.

(a) Off current

(b) On current

- $\mathrm{O}_{2}$ plasma treatment

- $\mathrm{N}_{2}$ plasma treatment 
次に，プラズマ処理を行った TFT のオフ電流特性と オン電流特性をさらに詳しく比較するために, ゲート電 圧 $V_{\mathrm{g}}$ を一定の電圧に固定し, ソース電圧 $V_{\mathrm{ds}}$ を変化さ せた場合のドレイン電流 $I_{\mathrm{ds}}$ (暗電流)の変化を測定した。 今回の実験では，対象となる現象を評価するための代表

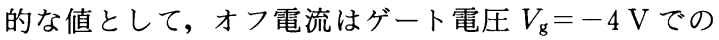
ドレイン電流 $I_{\mathrm{ds}}$ を,オン電流はゲート電圧 $V_{\mathrm{g}}=10 \mathrm{~V}$ でのドレイン電流 $I_{\mathrm{ds}}$ を測定した。

図 3 (a)に示すように, $\mathrm{N}_{2}$ プラズマ処理を行った TFT のオフ電流は, $\mathrm{O}_{2}$ プラズマ処理を行った TFT よ り低い。一方, 図 $3(\mathrm{~b})$ に示すようにオン電流は，どちら の場合もほとんど同じであった。

これらの結果から， $\mathrm{N}_{2}$ プラズマ処理は, TFTのオ ン電流特性に影響を及ほさざにオフ電流を低減できる効 果があることが判明した。

\section{2 オフ電流の光強度依存性}

これまでの評価で $\mathrm{N}_{2}$ プラズマ処理が，暗状態でのオ フ電流特性の改善に効果があることが確認できたので, 次に光照射時のオフ電流特性を評価した。

図 4 に, $\mathrm{O}_{2}$ プラズマ処理および $\mathrm{N}_{2}$ プラズマ処理を 行った TFT のオフ電流の光強度依存性を示す。光源と しては, メタルハライドランプを用い, 光をガラス基板 の反対側から TFTに照射し, ゲート電圧 $V_{\mathrm{g}}=-4 \mathrm{~V}$, ソース電圧 $V_{\mathrm{ds}}=10 \mathrm{~V}$ でのオフ電流を測定した。その結 果, バックチャネルエッチング後のチャネル領域の a$\mathrm{Si}$ : $\mathrm{H}$ 層の膜厚が同じであるにもかかわらず， $\mathrm{N}_{2}$ プラ ズマ処理を行った TFT の光照射下でのオフ電流は, $\mathrm{O}_{2}$ プラズマ処理を行ったTFTの約 $1 / 2$ に低減された。

\section{3 オフ電流の温度依存性}

図 5 に, $\mathrm{O}_{2}$ プラズマ処理および $\mathrm{N}_{2}$ プラズマ処理を 行った TFT のオフ電流の温度依存性を示す。温度は室

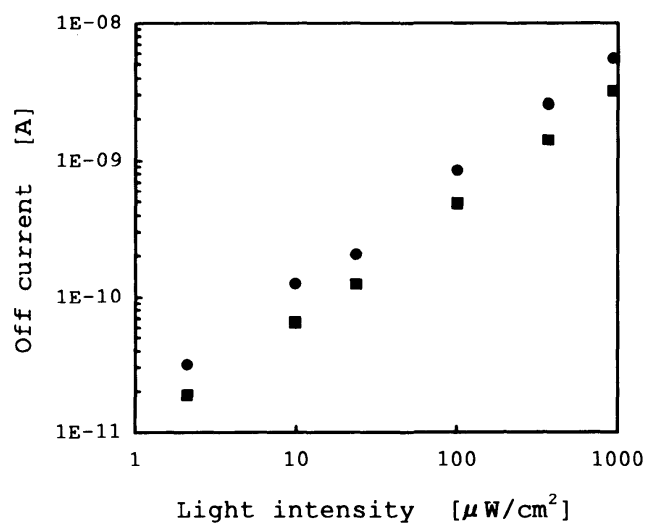

Fig. 4 Light intensity dependence of the off current.

- $\mathrm{O}_{2}$ plasma treatment

- $\mathrm{N}_{2}$ plasma treatment

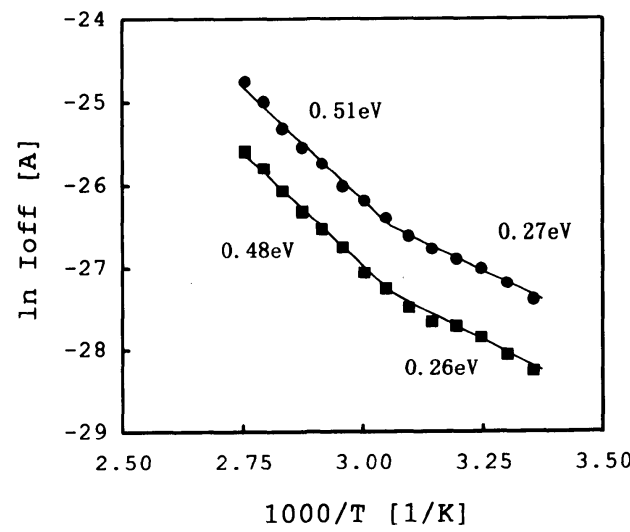

Fig. 5 Temperature dependence of the off current.

- $\mathrm{O}_{2}$ plasma treatment

- $\mathrm{N}_{2}$ plasma treatment

温から $90^{\circ} \mathrm{C}$ で変化させ，ゲート電圧 $V_{\mathrm{g}}=-4 \mathrm{~V}$, ソース電圧 $V_{\mathrm{ds}}=10 \mathrm{~V}$ でのオフ電流を測定した。 $\mathrm{N}_{2}$ プ ラズマ処理を行った TFT のオフ電流は, $\mathrm{O}_{2}$ プラズマ 処理を行った TFTに比へ，測定温度域すべてで低い値 となった。一方，活性化エネルギーについては， $\mathrm{O}_{2}$ プ ラズマ処理の場合も $\mathrm{N}_{2}$ プラズマ処理の場合もほとんど 同じ結果となった。このことから，プラズマ処理による ギャップ中のエネルギー準位の変化はないものと思われ る。

\section{4 信頼性評価}

TFT をLCD のスイッチング素子として用いる場合

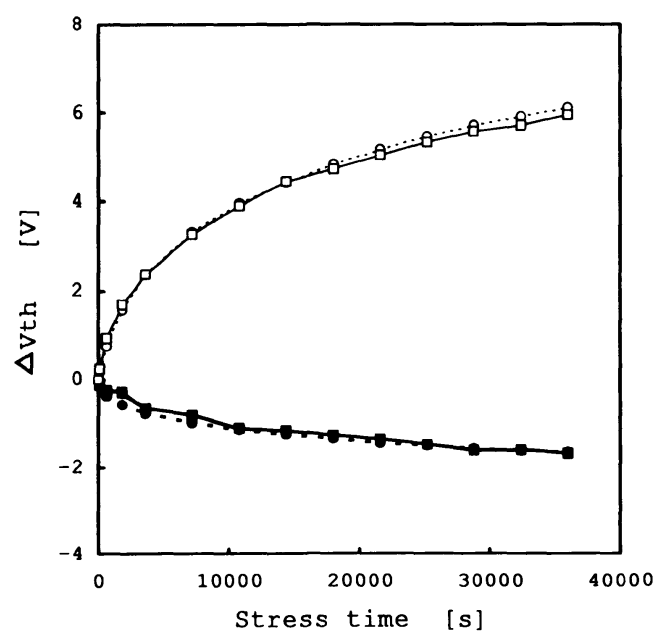

Fig. $6 V_{\text {th }}$ change of the TFTs under bias and temperature stress.

- $\mathrm{O}_{2}$ plasma treatment $V_{\mathrm{g}}=-20 \mathrm{~V}$

- $\mathrm{N}_{2}$ plasma treatment $V_{\mathrm{g}}=-20 \mathrm{~V}$

$\mathrm{O}_{2}$ plasma treatment $V_{\mathrm{g}}=+20 \mathrm{~V}$

$\square \mathrm{N}_{2}$ plasma treatment $V_{\mathrm{g}}=+20 \mathrm{~V}$ 

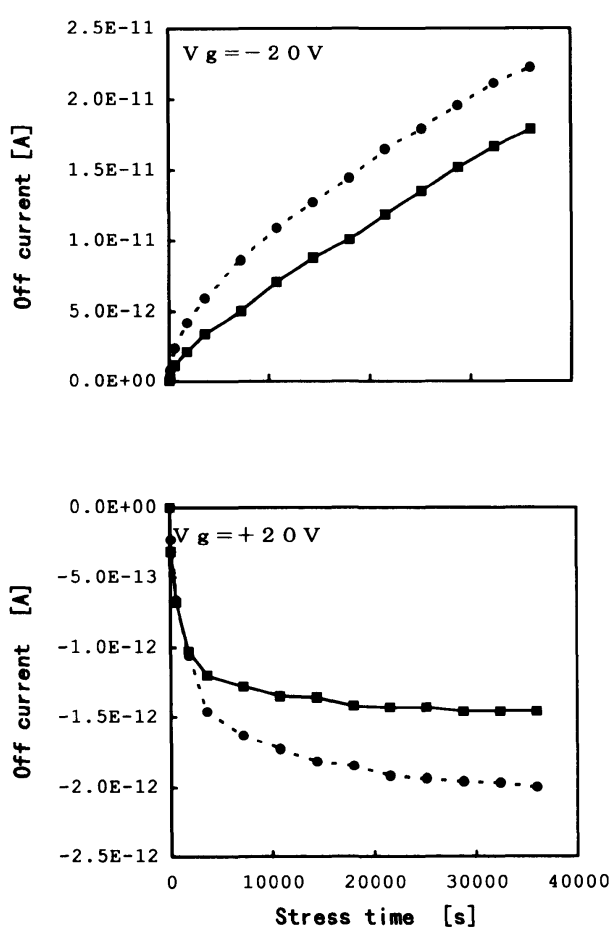

Fig. 7 Off current change of the TFTs under bias and temperature stress.

- $\mathrm{O}_{2}$ plasma treatment

- $\mathrm{N}_{2}$ plasma treatment

に, しきい值電圧 $\left(V_{\mathrm{th}}\right)$ の変動が重要となる ${ }^{3)}$ 。そこで, TFT の信頼性を評価するためにバイアスー温度ストレ ス(BTS)試験を行った ${ }^{4), 5)}$ 。バイアス, 温度のストレス 条件としてゲート電圧 $V_{8}$ は $+20 \mathrm{~V}$ および $-20 \mathrm{~V}$, 温度 は $60^{\circ} \mathrm{C} て ゙$ 評価を行った。BTS下での, TFTの $V_{\mathrm{th}}$ シ フトを図 6 に, オフ電流の変化を図 7 に示す。なお,才 フ電流はゲート電圧 $V_{\mathrm{g}}=-4 \mathrm{~V}$, ソース電圧 $V_{\mathrm{ds}}=10 \mathrm{~V}$ で測定した。

その結果 $\mathrm{N}_{2}$ プラズマ処理, $\mathrm{O}_{2}$ プラズマ処理いずれ の場合でも， $V_{\mathrm{th}}$ シフトはほとんど同じであるが，オフ 電流の変化は $\mathrm{N}_{2}$ プラズマ処理の方が, $\mathrm{O}_{2}$ プラズマ処 理の場合に比べ小さいことが分かった。

通常 BTS 試験では, TFT 特性の変化は a-Si とゲー 卜絶縁膜の界面, すなわちフロントチャネルの影響を受

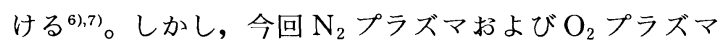
処理を行った TFT は, プラズマ処理を除いては同じ条 件で作製したため, フロントチャネルは同じ状態になっ ており, オフ電流の違いは, バックチャネルエッチング 後のプラズマ処理によって起こったものと考えられる。

\section{5 プラズマ処理の効果}

TFT オフ電流は, 種々の発生機構があるが, バック チャネルにおける欠宿密度と空間電荷量の影響も強く受 ける。すなわち，バックチャネルにおける欠陥は，その
エネルギー準位によって, リーク電流の元となる電荷の 発生源となる場合 (浅い準位) と, 電荷をトラップして動 きにくくする場合(深い準位)とがある。また，チャネル 保護膜に存在する空間電荷はバックチャネルのフェルミ レベルに影響を与え, オフ電流のゲート電圧特性に影響 する。

今回のようにバックチャネル表面にプラズマ処理を施 した場合は，バックチャネル界面の欠陷密度に影響を与 えると考えられる。図 5 の活性化エネルギーからもわか るように, オフ電流に関係するバックチャネルの久宿準 位は $\mathrm{O}_{2}$ プラズマ処理の場合も, $\mathrm{N}_{2}$ プラズマ処理の場 合も変わらず, 比較的浅い $0.27 \mathrm{eV}$ 付近と, 比較的深い $0.5 \mathrm{eV}$ 付近のレベルである。従って, $\mathrm{N}_{2}$ プラズマ処理 を行った場合には, $0.27 \mathrm{eV}$ 付近の欠陷準位が低減, あ るいは $0.5 \mathrm{eV}$ 付近の比較的樑いレベルが増加するため にオフ電流が低減すると考えられる。

今回の評価では, チャネル領域はソース・ドレイン電 極をマスクとしてドライエッチングを行ったが, a-Si TFT の製造プロセスに扔いては，フォトレジストでパ ターンを形成してチャネル領域のドライエッチングを行 い, その後, $\mathrm{O}_{2}$ プラズマによるレジストアッシング処 理を行う場合もある。そこで, $\mathrm{O}_{2}$ プラズマ処理の前後 に $\mathrm{N}_{2}$ プラズマ処理を行った場合のオフ電流特性につい て評価を行った。

図 8 に, $\mathrm{O}_{2}$ プラズマ処理の前後に $\mathrm{N}_{2}$ プラズマ処理

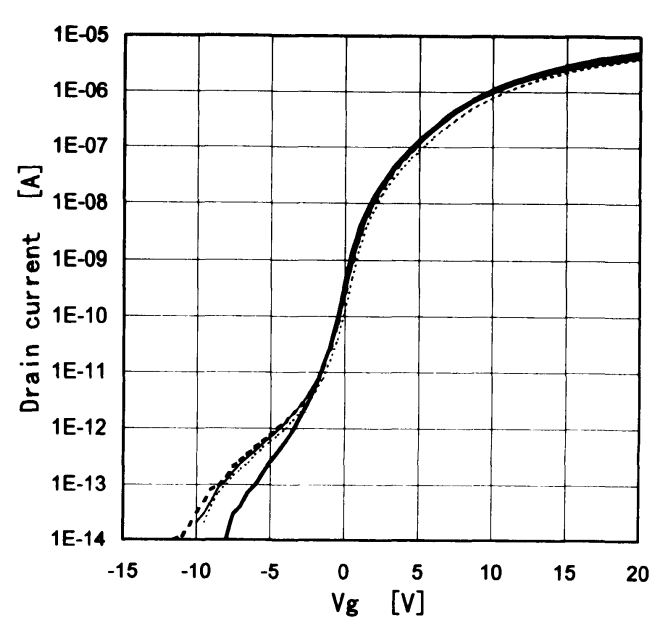

Fig. 8 TFT characteristics of the TFTs with $\mathrm{N}_{2}$ plasma treatment after and before $\mathrm{O}_{2}$ plasma treatment.

-...- $\mathrm{O}_{2}$ plasma treatment

$-\mathrm{N}_{2}$ plasma treatment

...... $\mathrm{N}_{2}$ plasma treatment before $\mathrm{O}_{2}$ plasma treatment

$-\mathrm{N}_{2}$ plasma treatment after $\mathrm{O}_{2}$ plasma treatment 
を行った TFT の特性を示す。 $\mathrm{O}_{2}$ プラズマ処理を行う 前に $\mathrm{N}_{2}$ プラズマ処理を行ったもの, $\mathrm{O}_{2}$ プラズマ処理 を行った後に $\mathrm{N}_{2}$ プラズマ処理を行ったもの, $\mathrm{O}_{2}$ プラ ズマ処理のみを行ったもの, $\mathrm{N}_{2}$ プラズマ処理のみを 行ったものの TFT 特性を各々示している。

それぞれのオフ電流特性を比較すると, $\mathrm{N}_{2}$ プラズマ 処理によるオフ電流の改善効果は, $\mathrm{N}_{2}$ プラズマ処理前 に $\mathrm{O}_{2}$ プラズマ処理を行うと得られなくなること, $\mathrm{N}_{2}$ プラズマ処理後に $\mathrm{O}_{2}$ プラズマ処理を行うと改善効果が なくなることが分かった。

したがって, バックチャネルエッチング後に, レジス トアッシングなどを目的とした $\mathrm{O}_{2}$ プラズマ処理を行う ことは,オフ電流特性を劣化させる要因となる。

\section{4. 結言}

バックチャネルエッチング後のプラズマ処理が, サブ スレッショルドの立ち上がり領域で, オフ電流に次のよ うな影響を及ぼすことが分かった。

(1) プラズマ処理を行うことで, オフ電流の変動が抑え られ，安定したオフ電流特性が得られる。
(2) $\mathrm{N}_{2}$ プラズマ処理を行うことで, 温度や光照射の影響 を受けずにオフ電流特性を改善できる。

(3) $\mathrm{N}_{2}$ プラズマ処理前後に $\mathrm{O}_{2}$ プラズマ処理を行うと, $\mathrm{N}_{2}$ プラズマ処理によって得られるオフ電流特性の改善 効果が消失する。

(Recieved June 15, 1998 ; Accepted January 11, 1999)

\section{文献}

1) M. Ando, M. Wakagi, T. Watanabe and T. Minemura: IDW '96/AM-LCD '96 Digest, p.45 (1996)

2) K. Kawai, T. Sakurai, M. Katayama, T. Nagayasu, N. Kondo, Y. Nakata, S. Mizushima, K. Yano and M. Hijikigawa; SID '93 Digest, p.743 (1993)

3 ) M. J. Powell ; Appl. Phys. Lett., 43, 597 (1983)

4 ）金子好之, 折付良二, 塚田俊久；TV 学会技報, ED 903, 31 (1985)

5 ) M. Ikeda, M. Dohjo and T. Aoki ; Jpn. J. of Appl. Phys., 26,1565 (1987)

6) M. Katayama, H. Morimoto, S. Yasuda, T. Takamatu, H. Tanaka and M. Hijikigawa; SID '88 Digest, p.310 (1988)

7 ) S. K. Kim, K. S. Lee, J. H. Kim, C. H. Hong and J. Jang ; AM-LCD '95 Digest, p.129 (1995) 